\title{
Serum-albumin and risk of thyroid cancer: A population-based, matched case-control study
}

\author{
E. Glattre ${ }^{1}$, A. Engeland ${ }^{2}$, E. Jellum ${ }^{3}$ and A.T. Høstmark ${ }^{4}$ \\ ${ }^{I}$ Cancer Registry of Norway, Montebello, N-0310 Oslo, Norway \\ ${ }^{2}$ National Institute of Public Health, Oslo, Norway \\ ${ }^{3}$ Institute of Clinical Biochemistry, National Hospital, Oslo, Norway \\ ${ }^{4}$ Section of Preventive Medicine and Epidemiology, University of Oslo, Norway
}

\begin{abstract}
NORSK SAMMENDRAG
Flere epidemiologiske undersøkelser fra 1980- og 1990-årene har funnet en invers assosiasjon mellom salbuminnivået og sykelighet/dødelighet av kreft. I utforskningen av skjoldkjertelkreftens etiologi og patogenese ble det derfor ansett som viktig å finne og bestemme styrken av en slik sammenheng når det gjelder skjoldkjertelkreft. Derfor ble alle med tilstrekkelig mengde serum deponert i Janusbanken og som senere i perioden 1973-1994, ifølge Kreftregisterets database, hadde fått skjoldkjertelkreft, identifisert - i alt 118 tilfeller. For hvert tilfelle ble det tilfeldig valgt ut tre friske kontroller med serum i Janus. Kontrollene ble matchet mot pasientene hva gjelder kjønn, alder, bostedsfylke og serums lagringstid. Etter dette sto man igjen med 114 tilfeller (78 papillære karsinomer, 19 follikulære og 17 av andre histologiske typer) og 333 kontroller. Albumin i serum ble bestemt med bromkresolgrønt-metoden og fri fettsyrer ble bestemt med en enzymatisk metode. Resultatene av denne populasjonsbaserte pasient-kontroll studien ble i korthet at man etter justering for fri fettsyrer ikke fant noen sammenheng mellom s-albumin og kreftrisiko for tilfeller der serum var tatt mer enn 6,6 år før diagnose. For serum tatt mindre enn 6,6 år før diagnose var det derimot en mulig positiv assosiasjon for de papillære karsinomene og en sannsynlig positiv assosiasjon for de follikulære karsinomene. Man fant altså ingen invers assosiasjon mellom s-albumin og skjoldkjertelkreft. I en kortfattet diskusjon omtales noen konfunderingsfaktorer som kan ha bidratt til resultatet.
\end{abstract}

Several recent epidemiological studies (1-6) support the existence of an inverse relationship between prior serum albumin concentration (s-albumin) and risk of subsequent cancer development in humans. During the 1990 's there was, therefore, considerable interest in this plasma protein and its possible role and unknown mode of operation in cancer prevention.

S-albumin plays an important role as regulator of osmotic pressure and other regulatory processes. It has the capacity to bind a large number of different substances, including fatty acids, hormones, metals, heme, bilirubin, trace elements and many therapeutic drugs, and therefore plays an important role in the transport of these substances. Both globulin (TBG) and prealbumin (TBPA) have thyroid hormone (TH) binding capacity, but this capacity is small compared to the TH binding capacity of s-albumin (7).

Human s-albumin has a molecular weight of almost 70,000 . It is made in the liver and contains 585 amino acids. It lacks associated carbohydrate and has a halflife of several weeks (8). Due to free cysteine, s-albumin seems to possess antioxidant qualities. S-albumin amounts to about sixty percent of all serum protein and can withstand fairly high temperatures for many hours. The gene for s-albumin is on chromosome four. Inherited structural differences in the albumin molecule may account for a certain amount of functional variation. Familial dysalbuminemic hyperthyroninemia is a disease characterized by elevated levels of TH caused by s-albumin's abnormally high affinity for TH.

The purpose of this study was to test and possibly verify the hypothesis that the serum concentration of albumin is inversely related to the risk of subsequent development of thyroid cancer. This hypothesis may be regarded as an inclusion in the more general hypothesis that s-albumin prevents cancer development.

\section{MATERIALS AND METHODS}

The Janus serum bank (www.kreft.no/forhelsepersonell/janusserumbank) was established in 1973 and contains one or more serum specimens from each of more than 300,000 Norwegian blood donors and participants in health surveys. The specimens are kept frozen at $-25^{\circ} \mathrm{C}$. Janus registration is based on the unique 11-digit personal number used for identification of Norwegian citizens. The Cancer Registry of Norway, which is a population-based and for all practical purposes complete database, applies the 11-digit number to identify a standardized, minimum data set of medical information recorded for every Norwegian cancer case diagnosed after 1952. 
All serum donors in Janus who developed thyroid cancer subsequent to serum donation, were identified by linking the Janus records to thyroid cancer records stored in the database of the Cancer Registry. For the period 1973-94 a total of 118 thyroid cancer cases with a sufficient amount of serum stored were identified. Each case was matched with three cancer-free and randomly selected serum donors by 1) age at the time of serum sampling ( \pm 1 year), 2) sex, 3 ) serum storage time and 4) county of residence. Three cases and eighteen controls had insufficient serum for the laboratory investigation, one case lacked controls and three controls lost their case. Altogether 114 cases and 333 controls were included in the analysis. Of the cases 78 had papillary carcinoma, 19 follicular carcinoma and 17 had other and rare diagnoses.

S-albumin concentration was determined by the bromcresol green method (9), with a reference interval of $0.54-0.77 \mathrm{mM} / 1$. The intra- and inter-assay coefficients of variation $(\mathrm{CV})$ were $2 \%$ and $6 \%$ respectively. Free fatty acids were assayed spectrofluorometrically by an enzymatic method, as described by Jebens and Sejersted (10). The reference interval for fasting free fatty acids concentration was $0.1-0.7 \mathrm{mmol} / 1$ - estimated as the mean $\pm 2 \mathrm{SD}$. The intra-assay $\mathrm{CV}$ was $1.7 \%$ and the inter-assay was $4.0 \%$.

Odds ratio estimates and $95 \%$ confidence intervals were computed using the LogXact program (Cytel Software Corporation, Cambridge, MA) and conditional exact logistic regression for three groups of cases and controls corresponding to the tertiles of the serum levels of controls (11).

\section{RESULTS}

Table I presents the relative risk (OR) of different forms of thyroid cancer for different concentrations of $\mathrm{s}$-albumin. The table shows no decreasing risk with increasing s-albumin. On the contrary, the table seems to suggest that the risk of follicular carcinoma and other morphological types may in fact increase with increasing s-albumin.

For the cases in this study, lag-time, defined as the interval between serum sampling and thyroid cancer diagnosis, ranged from 0.33 years to 21.33 years. The lag-time median divides the case-control sets into 57 with lag-time above 6.6 years and 57 with lag-time below 6.6 years. Table II presents OR by lag-time and $\mathrm{s}$-albumin for papillary and follicular carcinoma and for all morphologic types of thyroid cancer. The table shows that for lag-times above 6.6 years there is no indication of decreasing cancer risk with increasing level of s-albumin. Instead one finds an inversely u-shaped risk pattern with elevated risk for the medium time-lag as compared to the lower and higher s-albumin levels. This applies to papillary, follicular and all morphologic types. However, when replacing s-albumin tertiles with quintiles, this pattern disappears and OR by s- albumin becomes level for lag-times above 6.6 years (not shown). Table II suggests, on the other hand, that for lag-times below 6.6 years OR increases with increasing s-albumin.

Table III presents OR by stage and s-albumin for papillary and follicular carcinoma case-control sets with lag-times less than 6.6 years. The figures suggest that OR tends to increase with increasing s-albumin concentration for papillary and more clearly for follicular carcinoma irrespective of metastatic status. The numbers are very few, however, especially for the follicular type.

Table I. Thyroid cancer type, cases/controls, odds ratio and $95 \%$ confidence interval by level of prediagnostic serumalbumin level. Adjusted for free fatty acids. Linear trend.

\begin{tabular}{|c|c|c|c|c|}
\hline & & \multicolumn{3}{|c|}{ serum-albumin $(\mathrm{mmol} / \mathrm{l})$} \\
\hline \multicolumn{2}{|c|}{ Thyroid cancer } & $0.47-0.77$ & $0.78-0.85$ & $0.86-1.27$ \\
\hline \multirow[t]{4}{*}{ All } & $\mathrm{Ca} / \mathrm{Co}$ & $28 / 107$ & $48 / 119$ & $38 / 107$ \\
\hline & OR & 1.0 & 1.8 & 1.8 \\
\hline & $95 \% \mathrm{CI}$ & Ref & $1.0-3.6$ & $0.7-4.5$ \\
\hline & Linear trend & & $\mathrm{p}=0.09$ & \\
\hline \multirow[t]{4}{*}{ Papillary } & $\mathrm{Ca} / \mathrm{Co}$ & $22 / 68$ & $29 / 73$ & $27 / 89$ \\
\hline & OR & 1.0 & 1.2 & 0.8 \\
\hline & $95 \% \mathrm{CI}$ & Ref & $0.5-2.8$ & $0.3-2.5$ \\
\hline & Linear trend & & $\mathrm{p}=0.28$ & \\
\hline \multirow[t]{4}{*}{ Follicular } & $\mathrm{Ca} / \mathrm{Co}$ & $2 / 23$ & $13 / 24$ & $4 / 8$ \\
\hline & OR & 1.0 & 10 & 8.5 \\
\hline & $95 \% \mathrm{CI}$ & Ref & $1.5-\infty$ & $0.9-\infty$ \\
\hline & Linear trend & & $\mathrm{p}=0.10$ & \\
\hline \multirow[t]{4}{*}{ Other types } & $\mathrm{Ca} / \mathrm{Co}$ & $4 / 16$ & $6 / 22$ & $7 / 10$ \\
\hline & OR & 1.0 & 2.2 & 12 \\
\hline & $95 \% \mathrm{CI}$ & Ref & $0.3-21$ & $0.6-960$ \\
\hline & Linear trend & & $\mathrm{p}=0.08$ & \\
\hline
\end{tabular}

\section{DISCUSSION}

The main finding of this study, a population-based case-control study with 114 cases of thyroid cancer and 333 matched controls, was this: for serum samples taken more than 6.6 years prior to the thyroid cancer diagnosis, there was no association between level of salbumin and risk of thyroid malignancy. On the other hand, for serum samples taken less than 6.6 years before diagnosis a possible positive association was found between s-albumin concentration and risk of papillary carcinoma while a likely positive association was found between s-albumin concentration and risk of follicular carcinoma. Consequently, our results do not support the hypothesis that the level of s-albumin is inversely related to the risk of subsequently developing thyroid cancer.

Table I seems to show that the risk of subsequent diagnosis of papillary, follicular or any type of thyroid cancer is independent of concentration of s-albumin, or alternatively that the risk increases with increasing s-albumin concentration. In table II we used lag-time 
Table II. Thyroid cancer type, cases/controls, odds ratio and $95 \%$ confidence interval by lag-time and level of prediagnostic serum-albumin level. Adjusted for free fatty acids. Linear trend.

\begin{tabular}{|c|c|c|c|c|c|c|c|}
\hline & & \multicolumn{6}{|c|}{ Lag-time (years) } \\
\hline & & & $0.33-6.58$ & & & $6.67-21.33$ & \\
\hline & & sert & albumin $(\mathrm{m}$ & $\mathrm{b} / \mathrm{l})$ & seru & -albumin (m & $\mathrm{ol} / \mathrm{l})$ \\
\hline \multicolumn{2}{|l|}{ Thyroid cancer } & $0.47-0.77$ & $0.78-0.85$ & $0.86-1.27$ & $0.47-0.77$ & $0.78-0.85$ & $0.86-1.27$ \\
\hline \multirow[t]{4}{*}{ All } & $\mathrm{Ca} / \mathrm{Co}$ & $23 / 78$ & $19 / 58$ & $15 / 32$ & $5 / 29$ & $29 / 61$ & $23 / 75$ \\
\hline & OR & 1.0 & 1.4 & 3.3 & 1.0 & 3.0 & 1.7 \\
\hline & $95 \% \mathrm{CI}$ & Ref & $0.6-3.4$ & $0.8-15$ & Ref & $0.9-13$ & $0.4-9.1$ \\
\hline & Linear trend & & $\mathrm{p}=0.06$ & & & $\mathrm{p}=0.50$ & \\
\hline \multirow[t]{4}{*}{ Papillary } & $\mathrm{Ca} / \mathrm{Co}$ & $19 / 54$ & $10 / 36$ & $10 / 25$ & $3 / 14$ & $19 / 37$ & $17 / 64$ \\
\hline & OR & 1.0 & 0.9 & 1.9 & 1.0 & 2.4 & 0.9 \\
\hline & $95 \% \mathrm{CI}$ & Ref & $0.3-2.6$ & $0.2-18$ & Ref & $0.5-15$ & $0.2-6.6$ \\
\hline & Linear trend & & $\mathrm{p}=0.17$ & & & $p=0.73$ & \\
\hline \multirow[t]{4}{*}{ Follicular } & $\mathrm{Ca} / \mathrm{Co}$ & $2 / 17$ & $6 / 13$ & $3 / 3$ & $0 / 6$ & $7 / 11$ & $1 / 5$ \\
\hline & OR & 1.0 & 5.8 & 7.8 & 1.0 & 2.8 & 0.6 \\
\hline & $95 \% \mathrm{CI}$ & Ref & $0.6-\infty$ & $0.7-\infty$ & Ref & $0.3-\infty$ & $0.0-\infty$ \\
\hline & Linear trend & \multicolumn{3}{|c|}{$\mathrm{p}=0.07$} & \multicolumn{3}{|c|}{$\mathrm{p}=1.00$} \\
\hline
\end{tabular}

Table III. Lag-time $\leq 6.58$ yrs: Thyroid carcinoma, cases/controls, odds ratio and $95 \%$ confidence interval by metastasis status and level of pre-diagnostic serum-albumin level. Adjusted for free fatty acids. Linear trend.

\begin{tabular}{|c|c|c|c|c|c|c|c|}
\hline & & \multicolumn{6}{|c|}{ Metastasis status } \\
\hline & & & No spreadin & & & All stages & \\
\hline & & seru & -albumin (m & $\mathrm{l} / \mathrm{l})$ & seru & albumin (m & $\mathrm{ol} / \mathrm{l})$ \\
\hline \multicolumn{2}{|l|}{ Thyroid cancer } & $0.47-0.77$ & $0.78-0.85$ & $0.86-1.27$ & $0.47-0.77$ & $0.78-0.85$ & $0.86-1.27$ \\
\hline \multirow{4}{*}{ Papillary } & $\mathrm{Ca} / \mathrm{Co}$ & $11 / 37$ & $7 / 19$ & $7 / 18$ & $18 / 52$ & $9 / 32$ & $10 / 25$ \\
\hline & OR & 1.0 & 1.6 & 2.8 & 1.0 & 1.0 & 2.3 \\
\hline & $95 \% \mathrm{CI}$ & Ref & $0.4-5.7$ & $0.2-49$ & Ref & $0.3-3.0$ & $0.3-22$ \\
\hline & Linear trend & & $\mathrm{p}=0.08$ & & & $\mathrm{p}=0.15$ & \\
\hline \multirow[t]{4}{*}{ Follicular } & $\mathrm{Ca} / \mathrm{Co}$ & $2 / 14$ & $5 / 11$ & $2 / 2$ & $2 / 17$ & $6 / 13$ & $3 / 3$ \\
\hline & OR & 1.0 & 4.9 & 5.8 & 1.0 & 5.8 & 7.8 \\
\hline & $95 \% \mathrm{CI}$ & Ref & $0.4-\infty$ & $0.4-\infty$ & Ref & $0.6-\infty$ & $0.7-\infty$ \\
\hline & Linear trend & & $\mathrm{p}=0.13$ & & & $\mathrm{p}=0.07$ & \\
\hline
\end{tabular}

to show that the possible existence of a positive association between s-albumin and risk of thyroid cancer is restricted to the closest prediagnostic years. In several studies supporting an inverse association between salbumin and cancer in general, all cases for whom time between serum sampling and endpoint was less than $4-5$ years were eliminated before analysis $(3,4)$. For these studies we therefore don't know the sign of the association in the time period just before endpoint. On the other hand, the British United Provident Association (BUPA) study, a prospective study of 21,520 men, showed an inverse association between salbumin and cancer death only in the late latency period (12). In several studies the inverse relationship between s-albumin and cancer risk was shown to be restricted to males $(3,5)$. The question whether this is valid for thyroid cancer cannot be answered since gender is a matching criterium in the present study.

A great many events and exposures may operate as confounders in studies of s-albumin and risk of thyroid cancer. Smokers, for instance, tend to be lower in salbumin and have, especially in the case of women, a lower thyroid cancer risk than non-smokers. A halflife of several weeks makes s-albumin status insensitive to immediate changes in protein intake. S-albumin is on the other hand a good nutrition status and social class indicator. High s-albumin people may therefore have a higher cancer detection rate. Nutrition is thus a possible confounder, also. Further possible confounders are radiation, pregnancy and fatty acids. In this study, however, we have only been able to adjust for level of fatty acids in addition to the matching criteria 
i.e. age, sex, county of living and time of serum sampling.

The concentrations of serum components may alter during long-term storage. We have recently shown that albumin as well as free fatty acids may increase in concentration in response to years of storage at $-25^{\circ} \mathrm{C}$ (13). Due to the way case-sera have been matched with control-sera, there is no reason to believe that storage time has caused or influenced any of the results of this study.

It is, of course, possible that s-albumin is a vehicle for transport to the thyroid gland of special metabolites that stimulate tumour growth directly or indirectly. It is also a possiblity that s-albumin contributes to the removal of metabolites that tend to suppress cell proliferation. Since this study is a fairly small one and up till now the only one known to test prospectively the hypothesis about a negative association between salbumin and thyroid cancer risk, it is too early to come up with a rigid conclusion.

\section{ACKNOWLEDGEMENT}

The Janus serum bank is owned and financed by the Norwegian Cancer Society.

\section{REFERENCES}

1. Stevens RG, Kuvibidila S, Kapps M, Friedlaender JS, Blumberg BS. Iron-binding proteins, hepatitis B virus and mortality in the Solomon Islands. Am J Epidemiol 1983; 118: 550-561.

2. Stevens RG, Beasley RP, Blumberg BS. Iron-binding proteins and risk of cancer in Taiwan. JNCI 1986; 76: 605-610.

3. Stevens RG, Jones DY, Micozzi MS, Taylor PR. Body iron stores and the risk of cancer. N Engl J Med 1988; 319: $1047-1052$.

4. Phillips A, Shaper AG, Whincup PH. Association between serum albumin and mortality from cardiovascular disease, cancer, and other causes. Lancet 1989; 2: 1434-1436.

5. Darne B, Ducimetiere P, Guize L. Serum albumin and mortality. Lancet 1990; 335: 350-351.

6. Sweetnam PM, Yarnell JWG. Albumin and serum proteins. Lancet 1990; 336: 128.

7. DeGroot LJ, Reed Larsen P, Refetoff S, Stanbury JB. The thyroid and its diseases. New York, 1984.

8. Peters T. Serum albumin. Adv Protein Chem 1985; 37: 161-245.

9. Doumas BT, Watson WA, Biggs HG. Albumin standards and the measurement of sesrum albumin with bromcresol green. Clin Chim Acta 1971; 31: 87-96.

10. Jebens E, Sejersted OM. Enzymatic microdetection of plasma and serum free fatty acids. Scand J Clin Lab Invest 1992; 52: 717-724.

11. Mehta CR, Patel NR. Exact Logistic Regression: Theory and examples. Stat Med 1995; 14: 2143-2160.

12. Law MR, Morris JK, Wald NJ, Hale AK. Serum albumin and mortality in the BUPA study. Int J Epidemiol 1994; 23: 38-41.

13. Høstmark AT, Glattre E, Jellum E. Effect of long-term storage upon the concentration of albumin and free fatty acids in human sera. In press. 